\title{
Relations of Travel: Itinerary of a Practice
}

\author{
ANDREAS MOTSCH \\ University of Toronto ${ }^{1}$
}

Retraçant l'histoire de la relation de voyage jusquả la relatio en tant que témoignage dans un contexte légal, cet article souligne la nature performative de la relation en tant que pratique discursive. Il met également en lumière ses racines dans l'oralité et analyse les transformations qu'elle a subies dès le début de l'imprimerie jusqu'à la fin du XVIII e siècle. Le choix d'une approche performative place la relation dans un contexte plus large de pratiques humaines (culturelle, politique, économique, sociale) et offre un cadre différent à l'étude de la relation en tant que genre hybride de littérature de voyage dans le contexte plus large de la tradition littéraire. L'article analyse en détail l'essor de la relation durant la Renaissance en tant que compte rendu personnalisé de ce qui est étranger et éloigné, et identifie ses liens avec les traditions épistémologique et esthétique; ces traditions formant un corpus de principes désigné par l'expression ars apodemica, ainsi que le dialogue esthétique avec le roman naissant. Il explique donc le succès de la relation de voyage à l'époque moderne, son graduel déclin au profit d'épistémologies moins personnelles relevant d'un empirisme systématique, ainsi que sa curieuse survie due à la transformation du roman du fantastique au réalisme, préfigurant son succès renouvelé au XIXe siècle sous forme de récit de voyage.

\section{Introduction}

$\mathrm{T}$ ravel literature has enjoyed increasing interest within academic departments over almost three decades now, and finds itself today at the forefront of debates linking literary studies to many other disciplines. The reasons for this development are not properly literary. Born out of displacements driven by necessity or curiosity, or by economic, political, or spiritual pursuits, the history of travel and its textual legacies provide insight into the genesis of the Western episteme and the fashioning of the present worldview. ${ }^{2}$ Even so, 
literary studies remind us that any representation is also a discursive construct with its own poetics, something we need to be mindful of in the construction of disciplinary truths. If the poetics of travel has in the past been of minor importance, the focus changes when aesthetic criteria and value themselves are understood as historically contingent, allowing a fresh look at a textual legacy which is situated at a disciplinary crossroads.

Travel literature can be classified according to two taxonomic approaches. The first is an empirical typology, specifying the particular circumstances of travel; the second targets the modes of writing and its links to other genres by analyzing discursive production and poetic qualities of the text: narrative patterns, representational modes, construction of self and other, epistemic grounding, poetic qualities, and so on. The second approach not only reveals the internal functioning of the text by identifying rhetorical strategies; it also traces the text's relationship to a wider field of discourses, demonstrating its interdisciplinarity. Yet this methodology also requires a re-evaluation of literary discourse itself, liberating it from a narrow aestheticizing tradition in which it had become mired and integrating it into the general dynamic of discursive production and disciplinary formation.

We need to think about the genealogy and hermeneutics of the early modern relation in this broad context. As with any other genre, the relation has its own trajectory with its internal (poetic) and external (socio-historical) differentiations. The use of the definite article here suggests more clarity than the genre possessed. While texts entitled Relation vary greatly and frequently contain elements of other genres, many texts "relate" travel without being specifically labelled "relation," and yet are counted as such. It is difficult if not impossible to distinguish a "relation of travel" from titles such as "History of a journey," "Voyages and travels," "Voyage et aventures," etc. This ambiguity affecting travel literature and the travel relation is systematic and in the end constitutive of the genre, and the difficulty of distinguishing between them presents a challenge to anyone who seeks to address the question. Some aspects of this overlap have received scholarly attention, most notably the question of genre definition ${ }^{3}$ and the issue of cross-fertilization between travel writing and the emergent modern novel in the seventeenth and eighteenth centuries. ${ }^{4}$ The influence of both on the development of new philosophical ideas is also well documented. ${ }^{5}$ The travel relation as a particular genre, however, has so far received little attention, despite countless studies of individual texts. 
This article sketches the itinerary of the travel relation as a discursive practice from the beginning of print to the eighteenth century. It does so within the larger context of travel literature, of which it is an integral part, and of the historical and epistemic shifts marking European history. Tracing this development requires a constant shifting between the general, travel literature, and the specific, the travel relation as a particular practice or genre. To shed light on the itinerary of the travel relation we need to revisit the shared history of travel writing and the novel, and further draw on the discourse of travel itself (known as ars apodemica) and the political and epistemological changes affecting it. Beyond the purview of a narrowly defined literary debate, these lines of inquiry restore the interdisciplinary complexity of the object and methods of study. However, before this analysis unfolds I want to introduce its object in two comparative digressions: first, a look back in time to the etymological history of the term relatio; second, an inventory of texts bearing "relation" in their title as material witness for historical practices. Drawing from these surveys, I then develop an analysis of the early modern travel relation as a discursive performance and follow its historical and literary fortunes.

\section{Etymology}

The notion of relation as a particular mode of discourse becomes clear when we examine its etymology and history. ${ }^{6}$ Relation goes back to the Latin relatio, a noun derived from the supine relatum, which is itself a form of the compound verb referre (re+ferre); ferre means to bring, to carry and re-introduces the element of repetition or return, resulting in to bring back or to carry again. As a particular verb form, the supine expresses finality: relatum thus translates as in order to bring back. Relatio as discourse can in particular refer to a presentation of a matter to the Roman senate or its referral back to the magistrate, to a returning of discourse or statements in a legal context; in general it means to make a report, to give an account of events. That legal sense lived on as a technical term in medieval Latin law.

Inherited from the Latin, relation is documented in Old French in the early thirteenth century as a borrowed term in the sense of a report, mostly in the syntagm faire relation - stressing its performative value - and it contains a clear judicial value as testimony or deposition: an account, an official or a 
layperson gives of something about which he has knowledge. The latter meaning is documented in French jurisprudence up to the eighteenth century. More generally, as was the case in Latin, it simply means an account of a matter of fact. With the rise of exploration in the centuries ahead, relation comes to mean in particular a narrative account of an expedition to faraway lands, and from the seventeenth to the nineteenth century terme de relation refers to a word used in foreign lands which might eventually be borrowed. English acquires the term from Middle French late in the fourteenth century with roughly the same semantic values, including the judicial context where it means to give an account of a claim or a complaint to the court.

The English to relate is based on the French relater, a learned derivation from relatus and first documented in French in 1342 as meaning to tell something in a precise and detailed manner, or to report. As specific context, the dictionaries identify a procedural meaning: a presentation made to a legal authority. Relater is thus to tell, to narrate and to report, to give an account in the context of legal procedures.

Although in usage the noun seems to antedate the verb, it is useful to think of a relation as a performance. This is not merely because the noun is already based on a verb expressing an activity. Both common syntagms, faire relation and to make relation, stress the process of speaking, underlining the performative aspect. The expression thus draws attention to the issues of orality and literacy, and to the specific circumstances of reporting or bringing back. In the context of orality, to relate is to speak - but not just any form of speech. Relating happens in concrete situations, under particular circumstances and according to specific patterns. We therefore need to keep in mind Austin's How to do things with words, ${ }^{7}$ consider how relating is structured as a performance, and study the circumstances under which it takes place. This inquiry cannot be restricted to orality, but needs to address the advent of literacy as well as the consequences of the emergence of print. To be sure, the highly contextual nature of these performances as well as their frequency made for a great spectrum of relations so that their diversity challenges classification. Yet, as the dictionaries also reveal, relations form and conform to patterns and follow pre-established strategies. 


\section{Inventory}

Before analyzing relations as discursive patterns and relations of travel as a specific literary genre, let us look at the actual documents. While the search for origins is fraught with problems, it also provides insights. Indeed, the use of relation as travel report is well established before the invention of print, and even more so the meaning of relation as a report in general. The distinction here is often arbitrary. A quick survey ${ }^{8}$ of catalogues for the first occurrence of the term in a title and a print title in particular yields the following results.

As the term relatio goes back to Latin, it is fair to assume a continuity of use from Latin to the Romance vernaculars. Its Latin occurrences are difficult to trace as most texts are manuscripts and do not necessarily bear titles. An early candidate for relatio as a travel report might be Saewulf's relation of his pilgrimage to Jerusalem ${ }^{9}$ from the beginning of the twelfth century. While we find relatio appearing in a printed title as early as Giovanni Francesco Pavini's report on Bonaventura's canonization of 1482, published between 1486 and $1494,{ }^{10}$ the earliest use of the term to title a travel account is in the Jesuit relations concerning the missions to Japan and Peru at the turn of the seventeenth century, the first being Luís Froís' Nova Relatio Historica De Statu Rei Christianae In Iaponia... (1598). ${ }^{11}$

The situation is clearer in other languages. In English the first occurrence of relation in the title of a printed travel account is Sir Walter Raleigh's The discoverie of... Guiana with a relation of the great and Golden Citie of Manoa ${ }^{12}$ published in 1596. But in 1583 there had already appeared a Relation of the expongnable attempt and conquest of the yland of Tercera... by Don Álvaro de Bazán, a military report on the recapture of Terceira on behalf of Filippe II. ${ }^{13}$ In French, relation appears no later than 1558 in the translation of Francisco Álvarez's Historiale description de l'Ethiopie, contenant vraye relation des terres et païs du grand Roy et Empereur Prete-Jan. ${ }^{14}$ Hypothetically this title could be the result of its translation from Portuguese, but the original speaks instead of Verdadera Informaçam. ${ }^{15}$ Yet the term does exist in Portuguese print, because the earliest travel account is a Breve relação da embaixada que o patriarcha $D$. João Bermudez trouxe do imperador da Ethiopia ... (1565). ${ }^{16}$ In Spanish the earliest is Hernán Cortéz's Carta segunda de relación... (1522) on the conquest of Mexico, ${ }^{17}$ and in Italian we find published relazioni of a political nature at 
least since $1557 .{ }^{18}$ In 1563 we find the Relatione dell'Isola Giapan on the title page of Ramusio's Navigazioni et viaggi. ${ }^{19}$

The English tradition is rooted in the French, but the German case lies outside the Romance languages and presents an interesting contrast. Relation for travel accounts is very rare and suggests, if not a "borrowing," a foreign influence due to translation, for example on the title pages of Tavernier's Vierzig-Jährige Reise-Beschreibung. ${ }^{20}$ Yet the term is used frequently for reports on military or political expeditions and, intriguingly, news reporting in general and printed news in particular. Relation appears as early as 1566 in a broadsheet on the Turkish conquest of Szigeth. ${ }^{21}$ More significantly though, in German Relation rapidly comes to designate a serial publication for international news, for example in the periodical Relation: Aller Fuernemmen und gedenckwuerdigen Historien so sich... Inn diesem 1609. Jahr verlauffen und zutragen möchte. ${ }^{22}$ However, it should be stressed that this aspect of political news reporting is often echoed in the other languages.

\section{Three aspects of the relation}

Combining the results of both surveys, we are now in a position to discuss three constitutive aspects of the relation as a genre. Well before becoming a literary genre, the relation is first of all a performance: a discursive practice of speaking about a matter of importance, of giving a report about an event. The etymological roots and the strong dependence on the verb form are eloquent and confirmed by the factual use, as all relations point to some practice of witnessing events. The legal context best highlights the crucial features: the actual presence of the person speaking about a matter of fact in front of a court or magistrate. While referential in nature and in intent, the value of this discourse depends on the competence of the speaker, who bears witness out of personal experience and thus personal knowledge, so that the moral and epistemological value of what is said is indeed based on the witness' experience, prestige, and ethics. Furthermore, the judicial procedure is dialogical in nature: while a lay person or a magistrate presents an account of things that happened at another place and in another time, the court procedure itself makes it possible to examine the accountability of the witness in his or her presence. The performance is similar outside the legal context, where consequences can also be serious. Political 
or military reports for example have their own context of enunciation, their own political and social impact. It is therefore vital to attend to the situation of utterance and its broader context, often profoundly marked by power relations.

The second aspect is the institutional framework of such performances. The legal example is not alone. Reporting has its motives, and its subject matter is of public importance - be it a battle, the visit by an embassy, a beatification, a new land discovered, or the exploits of commerce. The overwhelming majority of texts identifying themselves as relations have a political dimension and function within an institutional framework. In the emerging bureaucratic administrations of early modern Europe, both travel and reporting engaged the military, the Church, state administration, and commerce. The relation of travel is thus one among many; to single it out remains problematic, as the example of Cortéz shows. ${ }^{23}$ Among all reports identified as relations in their title, those on travel constitute a small number; this is also true with respect to other texts reporting on travel, which are more often than not entitled History, Narrative, Truthfull description, etc. But while travel accounts entitled Relation were always a smaller percentage of the whole, they nevertheless were very important. Often written by missionaries, typically Jesuit, their number grows in the seventeenth century. While their genre classification is ambiguous as they originate in the Jesuits' yearly letters, their role in the institutional framework of the Jesuit order is well established.

The third aspect is implicit in the previous two: truthfulness. Relations entertain a privileged relationship to truth which is itself the result of complex procedures. Giving testimony invokes a rather formal reporting to some higher authority - worldly or spiritual - with its own rules, and truth itself can be seen as a rhetorical effect validated by particular discursive strategies. Much as in French customary law, where "faire une disposition de ce qu'on sait de quelque chose"24 is a judicial process of establishing facts about a matter based on personal experience, emissaries, missionaries, or other travellers might have to account for their travels and deeds. As in court, credibility and accountability are most important, and personal experience as opposed to hearsay or having read something elsewhere is crucial to a witness' credibility. This cannot be stressed enough, as travel brings the narrator well beyond the boundaries of the known world, where familiar categories no longer hold and where what is actually true might appear nonsensical, meaningless, pure imagination, or a lie. This conundrum is famous: while the relation as a personal account of travel 
has a privileged relationship to witnessing, the public often sees travel literature as questionable - if not as mere fantasy - and its authors are denounced as liars. Once again, the context of the performance, the quality of the observation, and the integrity of the observer-narrator can overcome these difficulties, but without additional verification no warranty can be given and competing truths might simply coexist.

\section{The shift to print}

Once absorbed by a culture of print, the performative aspect was no longer a distinct and defining feature for a relation of travel; the distinction between the relation as a practice based in orality, and travel writing in general, was blurred further. Traces of orality, however, did persist. The testimonial-performative dimension is alluded to in many texts, and titles can be quite explicit. For example, Sir Francis Drake's main title, The Voyages and travels... into the West-Indies, and round about the world is followed by Giving a perfect relation [emphasis added] of his strange adventures, and many wonderful discoveries ... ${ }^{25}$ Similarly, William Lithgow's The totall discourse of the rare adventures ... wherein is contained an exact relation [emphasis added] of the laws, religions, policies and governments..${ }^{26}$ presents the relation as a specific part, while also announcing what to expect, a "totall discourse," an exhaustive narrative. A pattern well established, a relation is always identified as a form of discourse about something: a true relation of the travels, a summary and true relation, etc. ${ }^{27}$

The oral past is further thematized in the framing of the traveller's discourse by the narrative voice itself. Travel reports regularly explain their raison d'être and in the preface or dedication name the institutions or authorities behind the text. In addition, their mode of dissemination provides further insights. For example, Francesco Carletti's Reflections on his travels (my translation) ${ }^{28}$ were not destined for publication, but conceived as a report to the Grand Duke of Tuscany to further the duke's commercial ambitions and to satisfy his curiosity. After his return to Florence in 1606, Carletti told Ferdinand I de Medici and his family about his travels in a series of encounters. Without his notes, which had been confiscated, Carletti relies on memory, but when he brings his reflections to paper between 1608 and 1615 he supplements them by consulting other sources. ${ }^{29}$ These Ragionamenti or Conversations or Reflections follow up on the 
meetings with Ferdinand and reflect that oral performance in their structure: they pretend to be reflections made in the presence of the most serene Grand Duke. ${ }^{30}$ Each chapter coincides with a meeting as well as a specific topic; their discourse addresses the Grand Duke and contains cross references to other talks, and the style remains close to conversation. Carletti clearly preserves the framework of the oral testimony, speaking and writing in his own voice as a seasoned merchant traveller, talking about events in a conversational and objective manner.

Carletti's double enunciation highlights important issues. First, it shows two enactments of the performance: one oral, and a following written version that augments and processes the material. Second, the fact of lost field notes both validates and subverts the authenticity of direct speech as unmediated testimony. Third, note the double authorship of oral and written discourse which is more typical of third person accounts where one person writes down what another one told him. This device is very common, appearing for example in the prominent narratives of Odoric of Pordenone's and Nicolo de Conti's journeys to Asia. ${ }^{31}$ Written down by persons "merely" documenting the traveller's discourse, the two narratives shape orality in different ways as they remind the reader of the testimony given. Because of the acknowledgement of their debt to oral testimony, these examples shed light on the complexity of the shift towards an economy of print. Their institutional contexts are explicit: Carletti reported to the Grand Duke, and Odoric and de Conti to religious authorities. All three texts "performed," offering up desired information. Once their testimony was made public through print, it circulated among a larger, more varied audience, but the text still acknowledged the context of its production. Without the persistence of such traces from orality - the "giving voice" - the process of generating discourse can still be documented by the narrative voice, but it will be an acknowledgment of writing discourse, and in the end the oral past can easily be masked. The text then no longer appears as the transcript of a performance, but as an object in its own right, a document to be studied.

If relations were originally oral presentations in front of an authority or audience, things change forever with the advance of writing and the invention of print: testimony becomes textually based, and this has profound consequences. While the objective of evaluation remains - to learn the truth about some matter - the modes of establishing and analyzing it shift. The performance of 
telling is now mediated through writing, printing, and reading, and it is marked by the spatial and temporal separation between the production, dissemination, and reception of a text. The immediate milieu of testimony shifts towards a monological exposition where the text alone mediates between author and reader. Dialogue gives way to textual hermeneutics and a history of reception. Yet if print spells the end of the relation of travel as an oral performance, it also ensures its future success.

\section{The rise of the relation}

It is time to take another look at the corpus and its relationship to print. The proliferation of relations of travel between the sixteenth and eighteenth centuries - as demonstrated by my inventory above - happens within the general context of travel literature, which is itself a result of the explosion of European exploration, the development of missions, trading posts, work stations, and colonies, and the concomitant expansion of knowledge. Travel literature occupies a central role in the satisfaction of curiosity and the establishment and dissemination of knowledge. Its flourishing not only parallels the intensification of discovery and mobility, but also the expansion of literacy and the development of print culture. As its overall volume increases dramatically, the number of travel relations increases as well. In my survey the proportion of relations of travel to relations of other events shifts significantly when foreign lands become a focus for society. If merchants, missionaries, and settlers needed to learn about the new lands they were to inhabit, others simply satisfied their curiosity, and travel literature not only became a privileged source of information but also offered models of conduct for future travellers.

The cumulative thrust of this development is visible in the publication of travel collections and related encyclopedic literature. Individual narratives are quickly translated, bundled, and redistributed in collections with their own economic and ideological agenda, for example Ramusio's Navigationi et viaggi, ${ }^{32}$ Hakluyt's Principal Navigations, ${ }^{33}$ or Theodore de Bry's series on the Western and Eastern Indies. While Hakluyt promoted English settlement

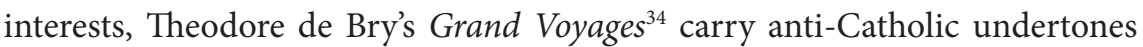
meaningful only in the context of the wars of religion and Protestant exile. Yet an interested reader might still buy the book, ensuring its commercial success. 
While these collections are always augmented and republished, they do remain, however, collections of individual works.

The situation is different with the Jesuit publications, whose very substantial impact requires special mention. The annual reports that missionaries sent to their superiors were carefully edited, printed, and disseminated to further the missionary cause and to gather financial and political support for the Jesuit order. Such reports were circulated individually from the inception of the order in 1540, and eventually reached a wide distribution thanks to the Jesuits' global network; but in the seventeenth century the French branch developed two serial publications. ${ }^{35}$ The first one, the "Jesuit Relations," contains about 40 volumes published from 1629 to 1673 with titles always structured in the same way: for example, Relation de ce qui s'est passé en la Nouvelle France, en l'année 1633, envoyée au R[évérend] P[ère] Barth. Iaquinot, Provincial de la Compagnie de Jesus en la province de France par le P. [ère] Paul le Jeune de la mesme compagnie, Superieur de la résidence de Kebec. ${ }^{36}$ The books contain not only news about the missions in New France whose destiny can thus be followed by the reader year by year, but also precious information about the land and its inhabitants. Because of their institutional nature and their editorial treatment, the Jesuit Relations are a combination of internal reporting, edifying literature, and periodical news reporting - the latter feature reminding us of the characteristics of the German Relation. Their impact was substantial and their popularity helps to explain the proportionate increase specifically in relations of travel in the seventeenth century. The aspect of periodical news reporting is less prominent in a second, later series, whose title emphasizes moral edification and the satisfaction of curiosity: Lettres édifiantes et curieuses écrites des missions étrangères par quelques missionnaires de la Compagnie de Jésus. ${ }^{37}$ This series, running from 1703-1776, counts 34 titles organized around geographic areas, with a strong concentration on Asia, especially China. Offering some diversity in genre, the series contains mostly letters of a highly informative nature. If the publications are still chronological, the pattern of a yearly report from the same place to a central administration gives way to a more flexible yet more concentrated presentation of the subject matter. The Lettres announce in this respect the encyclopedic approach of the Enlightenment, celebrated in series such as the Histoire générale des voyages of the Abbé Prévost ${ }^{38}$ where individual travel reports are synthesized. The result is an increasingly objective - that is, critically evaluated - text reduced to 
condensed facts, a report where the narrative voice becomes less and less a witness and more a critical commentator and compiler of primary material, and eventually disappears completely. Although single travel relations did influence European thought, it was the publication of collected voyages, and then of encyclopedic works based on travel narratives, that abetted an epistemic shift and fed the instrumentalization and commercialization of knowledge.

\section{Travel as education and entertainment}

The distance separating such collections of data from the raw material of personal testimonials is significant. Both seek to inform the reader, but travel literature needs to offer knowledge in an engaging way. Horace's requirement of the poet, aut delectare aut prodesse, to entertain or to instruct, becomes in the Renaissance the double requirement to entertain and to instruct, soon a key topos of travel writing. As travel educates the traveller, travel literature educates the reader, but without exposing readers to any risks or asking much effort of them. Homer's Odyssey might well fall in that tradition; it points to the usefulness of the knowledge at stake. A topos in its own right, the Odyssey is frequently invoked as offering literary and historical precedent for a poet relating a hero's wanderings to enlighten the audience. ${ }^{39}$ As the figure of Odysseus, King of Ithaca suggests, no one can make better use of such knowledge than those who rule over others. The geo- and sociopolitical instrumentality of knowledge about other lands and peoples figures prominently as a quality of political leaders, and serves as a leitmotiv in the related encyclopedic literature, linking Renaissance Humanism to the educational agenda of the Enlightenment. The preface to Johannes Boemus's collection Omnium Gentium Mores, Leges et Ritus... ${ }^{40}$ in its English translation of 1555 expresses this succinctly:

And yeat this maner of knowledge and experience, is of it self so pleasant, so profitable and so praise worthy, that sundrie (as it is well knowen) for the onely loue and desire thereof, leauing their natiue countrie, their father, their mother, their wiues and their children, yea, throwyng at their heles their sauftie and welfare, haue with greate troubles, vexations, and turmoilynges taken vpon theim for experience sake, to cutte through the wallowying seas, and many thousande miles, to estraunge theimselues 
fro their home, yea, and those men not in this age alone, but euen from the firste hatchyng of the worlde haue been reputed and founde of moste wisedome, authoritie, and good facion, sonest chosen with all mennes consent, bothe in peace and warre, to administre the commune wealth as maisters and counsaillours, Iudges and Capitaines.

Two centuries later, the Jesuit Joseph-Fançois Lafitau is equally precise about the purpose of studying other cultures: one studies customs to form customs.

Ce n'est pas en effet une vaine curiosité \& une connoissance stérile que doivent se proposer les Voyageurs qui donnent des Relations au Public, \& ceux qui aiment à les lire. On ne doit étudier les moeurs que pour former les moeurs, \& il se trouve partout quelque chose dont on peut tirer avantage. $^{41}$

Despite their ideological and historical differences, the consensus of the humanist scholar, the Jesuit missionary, and, soon, the Enlightenment's own philosophe voyageur is overwhelming, and the new tradition of the Grand Tour in the eighteenth century confirms that "reisen bildet" (travel educates).

\section{Ars apodemica}

The pedagogy of travel, how one ought to travel, what one should observe, whom one should visit, how one ought to behave, and how then to write about it is the domain of ars apodemica, a systematic theory and methodology of travel. In addition to models inherited from Antiquity such as those provided by Herodotus, Pausanias, Homer and many others, early modern travel literature could rely on an arsenal of apodemic texts whose history mirrors the history of travel writing in general and of travel relations in particular. Justin Stagl has shown the importance of this literature for the development of the empirically based social sciences. ${ }^{42}$ Just as observations of foreign lands were useful for the natural sciences, descriptions of other societies offered empirical data for what would become the social sciences. The quality of such observations explains the role this information played in the expansion of knowledge, the development of epistemology, and the role of science in and for society in general. 
While this fact points to the crucial role played by apodemic literature, it does not explain the link between travel as a practice and its theory. Ars apodemica as the theory behind the methodization of travel is a product of humanistic educational reform and the encyclopedic methodology of data collection. It provides instructions for travel that seek to educate the traveller, and at the same time offers taxonomies to organize observations in an encyclopedic manner. Apodemic literature talks pragmatically about the definitions of travel (peregrinari, vagari, errare), its taxonomies (secular, religious, commercial, medical), its advantages and disadvantages; it offers moral and religious advice with respect to other customs, provides hygienic and dietary information, and makes suggestions concerning safety, language and communication, and necessary preparations, and tells what to see and whom to visit, how to observe and how to take notes while on the road..$^{43}$ It cautions the traveller against hearsay and values eyewitness testimony and note-taking while en route. As for the depiction of foreign lands, it suggests the traveller bring back names and descriptions of their geographic location and terrain, their population, the nature of their jurisdiction, and their monuments and products; and perhaps also fetch some specimens. Such exhaustive and detailed instructions are not shared by all apodemic texts. They vary in intent, interest, and perfectionism as well as in national tradition. Stagl explains how their strong pedagogic and systematic orientation is characteristic of late German humanism. ${ }^{44}$ Yet the results are the same: a quantitative and qualitative increase in data and their subsequent integration in evolving discourses of knowledge. One of these discourses is "statistics." Stagl reminds us how in the seventeenth century "statistics" refers to all there is to know for the statesman (statista), and that statistics is thus a qualitative and discursive discipline and not a merely quantitative one as today. ${ }^{45}$ Both Boemus and Lafitau simply repeat the topos of apodemic literature, the idea that travel and its textual legacies are part of the curriculum for political decision makers. As a body of knowledge, statistics gathers its material from descriptions of societies, religions, and states provided by all sorts of travel reports, and these reports rely in turn on the guidance of apodemic treatises for their own modi operandi. The discourse of the traveller is thus highly conditioned, if not overdetermined, by previous models as much as by the expectation of the audience. This is true not only of the subject matter, but also of the mode of presenting. The more travel itself assumed the traits of a method, or even of a nascent science, the better a travel narrative might claim 
persuasive authority thanks to its very subject and, implicitly, to the reliability of the orderly procedures recounted; the less an author had any longer to offer up his eyes and person as a guarantor of plausibility. Thus, gradually, apodemic writing helped undermine the personal dimension of the author for the relation.

\section{Competing genres}

The time has come to address the crucial issue of modes of discursivity and aesthetics, the relationship of the travel relation to other genres. We have seen how travel literature diverged, sometimes evolving into empirical discourses, but not always; it often entertained as well. When it did so, it tangled in complex ways with the evolution of the novel. Indeed, travel literature itself is marked by the multiplication and differentiation of discourses of knowledge. But a second major problem in this itinerary of the relation as a genre is also inseparable from travel literature in general. It concerns the complex relationship travel writing has with the novel. In this process, the itinerary of the relation cannot be divorced from the larger picture of travel writing because they share the available spectrum of discursive tools. After the satisfaction of curiosity, the crisis of the novel constitutes the other major factor in explaining the popularity of travel literature. At the end of the seventeenth century, the early modern novel, with its fantastical stories, was losing its readership. Travel narratives moved into the gap and gained the uncontested favour of the public, eventually helping to inspire a new model of the novel over whose aesthetics they exercised great influence. The analysis of this development cannot be revisited here, but some features need to be recalled in order to explain the success of travel writing as a "literary" genre, with its aesthetics and discursive proliferations. ${ }^{46}$ This excursus in turn will bring us back to the specific characteristics of the travel relation and, finally, to an understanding of its "disappearance" within a complex universe of discourses and practices.

The weakness of the novel at the time derived from its tradition of frivolous fiction. In the face of travel and historical writing the novel fell into discredit as, in a swiftly changing world, it did not allow its readers to engage with reality. If travel writing itself was not always free of imagination and fantasy, early modern travel writers nevertheless placed themselves in the service of truth and science. ${ }^{47}$ This tendency, as I have noted above, was itself the result of 
epistemological and political changes; the readers' interest in the unknown was quickly seized upon by Church and State, who used travel reports as political and missionary propaganda. The results in France and England diverged. In France the interest in travel literature hardly translated into successful colonial or commercial enterprises. It remained a more intellectual pursuit, forging ideas and stimulating conversation in salons, culminating in the debates of the Enlightenment. Yet in the seventeenth century the interest in travel literature was so great that it not only displaced the novel but overtook it in the esteem of the public. The literary critics of the day could not be clearer. Jean Chapelain for example wrote in a now famous letter of 1663 :

Notre nation a changé de goût pour les lectures et, au lieu des romans, qui sont tombés avec la Calprenède, les voyages sont venus en crédit et tiennent le haut bout dans la Cour et la Ville, ce qui sans doute est d'un divertissement bien plus sage et plus utile que celui des agréables bagatelles qui ont enchanté tous les fainéants et toutes les fainéantes de deçà, dont nos voisins italiens, allemands, hollandais ont sucé le vénin à leur dommage et à notre honte. ${ }^{48}$

This high esteem is also reflected in Charles Sorel's Bibliothèque française, ${ }^{49}$ a bibliographic survey of French literature. He places the section "Des Voyages" under the general heading of "Des Narrations véritables" before the various sections of the novel, and it is immediately followed by "Des Vies des Hommes celèbres \& Illustres," reminding us of the topos linking knowledge of travel and the exercise of political office. As a bibliographer and literary critic, and also the King's historiographer, Sorel mobilizes all the topoi extolling the benefits of travel writing, starting out with the classical examples, including Odysseus, before offering an inventory of travellers of his period, justifying it as follows:

Nous n'entendons parler que des Voyages que les Particuliers font ou par necessité ou par curiosité; la lecture des Liures qui en ont esté faits, est des plus agréables \& des plus vtiles : Les coustumes bigearres des Peuples nous servent de remercier Dieu de nous auoir fait naistre en vne contrée plus heureuse. Parmy les accidens estranges dont on void les Relations, on trouve tousiours quelque matiere d'instruction, \& en tout cecy le profit est 
grand de visiter tant de pays sans danger, \& de faire le tour du Monde sans sortir d'vne chambre. ${ }^{50}$

Sorel then gives an overview of "Relations" or "Livres de Relations," using relation consistently as a bibliographic classification and even referring explicitly to the "Volumes de Lettres \& de Relations des R. Peres Jesuites." Eventually, he also addresses the distinction between novel and relation, giving the example of Les Voyages de Fernand Mendez Pinto, ${ }^{51}$ providing a clue as to why travel writing overtakes the novel. Referring to criticism of Mendez Pinto's Voyages as "fabuleux," Sorel offers the following defense:

Qu'on appelle ce Liure vn Roman tant qu'on voudra, il ne laisse pas d'estre vne agreable lecture; Aussi, dit-on, Que [«] les Liures de Voyages sont les Romans des Philosophes [»], soit pour monstrer que les Philosophes y prennent autant de plaisir, que les Gens du Monde font dans leurs Romans, ou qu'ils tiennent pour des Fables les plus grandes Veritez de tous ces Liures-là, au prix de la certitude de leur Science. ${ }^{52}$

Sorel quotes here the increasingly popular topos to which Furetière's Dictionnaire pays homage, presenting travel narratives in the edition of 1727 as the "romans des honnêtes gens." ${ }^{33}$ Travel writing's entertainment value is competing with, and soon trumping, the entertainment value of the novel; and the opposition between truth and fiction, travel writing and the novel, is blurred. The double requirement to instruct and to entertain allows the travel writer to gain a wider recognition, but the wish to entertain can put him at odds with the truth. The issue of truthfulness which I have already identified is now situated in the wider context of contemporary epistemological and aesthetic shifts. The implicit opposition between literary entertainment and factual truth is resolved once the aesthetics shifts from the marvelous to some version of realism, namely the emerging classical paradigm valuing what is natural, simple, true and, tellingly, in conformance with reason. ${ }^{54}$

While this process is gradual, travel writers continue to confront a heavy prejudice because the general opinion holds that they are liars. ${ }^{55}$ The persistence of this topos, whose roots lie in Antiquity, is astonishing. Echoed within the French tradition by authors such as Bayle, Sorel, Montaigne, and Legat for example, the topos does not change despite the great appreciation of 
travel itself. The Chevalier de Jaucourt summarizes this situation aptly in his Encyclopédie entry on "voyageur":

VOYAGEUR, (Hist. particul. des pays.) celui qui fait des voyages par divers motifs, \& qui, quelquefois en donne des relations; mais c'est en cela que d'ordinaire les voyageurs usent de peu de fidélité. Ils ajoutent presque toujours aux choses qu'ils ont vues, celles qu'ils pouvoient voir; \& pour ne pas laisser le récit de leurs voyages imparfait, ils rapportent ce qu'ils ont lu dans les auteurs, parce qu'ils sont premiérement trompés, de même qu'ils trompent leurs lecteurs ensuite. C'est ce qui fait que les protestations que plusieurs de ces observateurs, comme Belon, Pison, Marggravius \& quelques autres sont de ne rien dire que ce qu'ils ont vu, \& les assurances qu'ils donnent d'avoir vérifié quantité de faussetés qui avoient été écrites avant eux, n'ont guere d'autre effet que de rendre la sincérité de tous les voyageurs fort suspecte, parce que ces censeurs de la bonne foi \& de l'exactitude des autres, ne donnent point de cautions suffisantes de la leur.

Il y a bien peu de relations auxquelles on ne puisse appliquer ce que Strabon disoit de celles de Ménélas: je vois bien que tout homme qui décrit

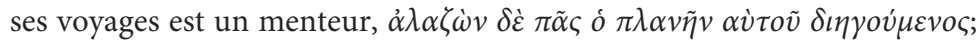
cependant il faut exclure de ce reproche les relations curieuses de Paolo, de Rawleigh, de Pocock, de Spon, de Wheiler, de Tournefort, de Fourmont, de Koempfer, des savans Anglois qui ont décrit les ruines de Palmyre, de Shaw, de Catesby, du chevalier Hans-Sloane, du lord Anson, de nos MM. de l'académie des sciences, au Nord \& au Pérou, \&rc. (D. J.) $)^{56}$

After a summary condemnation of the traveller-writer, Jaucourt discusses positive examples and counter strategies, and addresses the question of which style the traveller needs to develop in order for his text to appear (if not to be) truthful, and for himself to seem trustworthy. As we have already seen, beyond the scenario of personal testimony: the quality of the discourse plays a decisive role here. Once truth becomes the function of a text and a hermeneutical procedure, it is necessary to analyze what, at that point, comes of its strategies of truthfulness.

Beyond the first person narrator, the autobiographical dimension in general and the issue of eyewitnessing in particular, it is style or more broadly the question of language which needs to be addressed. As rhetorical artifice 
was seen as distracting from or contradictory to objective reporting, authors and critics advocated for a style devoid of literary ambition and poetic artifice. ${ }^{57}$ A straightforward way of reporting along with great simplicity becomes the discursive strategy of choice and its legitimization by the author another topos. Yet any style devoid of convoluted rhetoric is still a style, a mode of discourse, albeit different, and it still has to provide the reader with pleasure and instruction. Thus emerges a specific poetics of travel which situates the travel narrative at the margin of the literary and its lies, and which in turn shapes the new aesthetic of the "literary". 58 This poetics of travel - whose cornerstones are the precision of descriptions, the appeal of adventure, and the charm of the simple truth - leads in the second part of the eighteenth century to a renewed conception of the novel, which in Chupeau's formula seeks to "faire voir, faire vivre, faire vrai": to make [the reader] see, to make [the reader] experience and make [whatever is written appear] to be true $-\mathrm{a}$ formula pointing less to truth itself than to the power of discourse whose truth is anything but "simple."59

This evolution can be traced in the following examples of relations on two different levels. Lahontan demonstrates the discursive or literary differentiation of the travel relation within one single cuvre, as the author relates the same travel experiences in three different texts which were all published within a year. ${ }^{60}$ His relation entitled Nouveau Voyages de Mr. le Baron de Lahontan dans l'Amérique septentrionale; Qui contiennent une relation des différens Peuples qui $y$ habitent ${ }^{61}$ is a typical narrative which retraces chronologically two journeys in a series of 25 letters supposedly written en route, a sort of field correspondence. As his relation focusses on his displacements and occurring events, the reader follows Lahontan from Europe to North America and back, accompanying him from place to place until his return, retracing the journey and the accounts of the author's whereabouts, as if in a journal. The second text is a retrospective one, the Mémoires de l'Amérique septentrionale.... ${ }^{62}$ focussing in turn on ethnographic, geographic, and historical information which it regroups in thematic chapters, an approach indicative of the "encyclopedic" tendency discussed above. It is the third text, however, which accounts for the lasting reputation of the author. The Suite du voyage de l'Amérique ou Dialogues de Monsieur le Baron de Lahontan et d'un sauvage.... ${ }^{63}$ is a fictional dialogue between the author and an invented Native called Adario. Published at the outset of the eighteenth century, this philosophical dialogue is an informed criticism of European ethnocentrism and clearly announces the Enlightenment's polemic concerning the noble savage. 
While the Dialogues are a literary and philosophical exercise in their own right, they demonstrate the power of fiction to entertain but also to reflect the world and to influence the reader's view of it. All three texts are sequels ("suite"); they overlap in subject matter and are grounded in the same experience to which they bear testimony; but by adopting different discursive strategies they also testify to the literary options available to the author at a given time.

In the crossing of travel genres between the relation, the novel, the memoir, the journal, the dialogue, etc., it is not rare to encounter mixed breeds, and the second example shows a similar dynamic and variety within a single text: The Avantures du Sieur Claude Le Beau. Voyage curieux et nouveau parmi les Sauvages de l'Amérique septentrionale published in $1738 .{ }^{64}$ Claude Le Beau is a contemporary of Lahontan who also relates his travel to New France, but does so through an "intergeneric" text situated halfway between a true relation and the exotic novel. ${ }^{65}$ Using his more limited travel experience as the framework for his adventure plot, Le Beau compensates for what he lacks in first-hand knowledge with a fair amount of imagination and extensive borrowing from the books of other travellers and compilers. The result is a first-person narrative organized chronologically, in step with his movements on the continent, a narrative rich in suspense, picaresque adventure, and romance, which divulges, in numerous digressions, ethnographic, geographic, and historical information on land and people. This common narrative model, however, presents a particular challenge to the author of travel writing who needs to strike a balance between relating the action and describing land and people.

If the goal is indeed to entertain the reader and to instruct at the same time by making the reader see (faire voir), experience (faire vivre), and believe (faire vrai), the success of the narrative model depends to a great degree on the ability of the travel narrative to balance these two fundamental modes of discourse, the narrative and descriptive. A writing traveller such as Le Beau needs to report what he has seen as well as what happened, and often does so in a chronological way, interrupting the action with digressions - as do his novel and Lahontan's travel relation. If the action risks pushing the narrative into the vicinity of adventure novels and pure fiction, the description of land and people eventually pushes in the direction of documentary literature. Since any description necessarily disrupts the narration of events, this tension - if not antagonism - remains fundamental even though its manifestations change with the transformation of genres. When in the eighteenth century a renewed 
novel adopts travel as a favoured theme and discursive pattern, and when travel writing itself evolves either towards adventure and entertainment or into a more personal and eventually introspective genre, the narrative focus narrows and shifts away from the objective documentation of new worlds and historical realities. This is true for writing on travel in general and even more so for the travel relation, with its focus on objective testimony. In turn, the subjectivity of the traveller now moves towards the centre of the author's preoccupation, and it is the descriptive mode which accounts for the impression of events and things on the traveller's subjectivity, the exploration of his sensitivity and psyche. These transitions of discursive modes require writing skills a simple traveller might not have. Excess is a real risk either way, verging on poetic exoticism or a narrative of heroic adventures. Literary history has preserved a fair number of examples of each. Le Beau and Lahontan show and respond to these shifts in different ways: Le Beau by presenting a truly intermediate genre, and Lahontan by diversifying his æeuvre. Both present colourful, strong fictional narrators based on their personal experience. Both are travellers who write rather than authors who travel, write about it and then publish. Their successful exploration of different modes of discourse, their use of an array of "literary" tools that are anything but "simple," and the presence of a strong first-person narrator already announce the direction of the future novel which will transform the discursive landscape. The travel narrative will not remain immune to these developments as the changing taste of the audience reshapes the discourse of the traveller along with the entire spectrum of discourses. ${ }^{66}$

\section{Conclusion}

If the travel narrative in seventeenth-century France overtook the novel in the appreciation of the reader and imposed itself as the dominant epistemological model of the classical discourses of the period, ${ }^{67}$ it remained nevertheless an intermediate genre. With the emergence of a more realistic novel the travel narrative lost terrain, and did so not only in France. ${ }^{68}$ To continue to compete for the favour of the audience, it would have to reorient and reinvent itself. Travel literature had come to an important crossroads, and the type of travel narrative to which we have grown accustomed since the age of exploration 
vanished in the middle of the eighteenth century. The discursive landscape changed forever. What happened?

It would be absurd to assume that people no longer travelled or stopped relating their experiences of travel after the middle of the eighteenth century. On the contrary, travel increased, but the nature of travel and the circumstances and expectations of writing were quite different. By the eighteenth century, travel literature no longer commanded the same interest of the general public as it no longer yielded the sensational news it did before. The globe and its inhabitants were largely known and the exploration of foreign lands was increasingly framed either as personal adventure or scientific expedition. As Chupeau (for France) and Adams (for France and England) in their different ways have shown, the travel narrative and the novel parted company after a period of cross-fertilization and a profound transformation of the latter by the former. The novel largely made the aesthetic of the travel narrative its own by featuring travel as a privileged theme. In return, travel accounts eventually evolved in other directions, such as a more personal or introspective writing centred on the subjectivity and sensibility of the narrator, itself a prominent feature of the emerging novel, albeit not exclusive to it. ${ }^{69}$ In this regard the romantic travel account was already programmed. It was however not only the novel which parted ways with the travel narrative; with the transformation of the genre, the travel relation did so as well. This also spelled the end of the ambiguity between travel narrative and travel relation. While the travel narrative became free to take on features of the novel, the travel relation - as I have presented it here - did not. This was because of its special link to institutional reporting and its focus on telling the truth and establishing knowledge. It needed to adopt a different evolutionary path.

We have seen how the compilation of travel accounts transforms discourses of travel and leads to encyclopedic data collection. This, I suggest, is the direction the travel relation took. It is therefore logical that the dramatic decrease of travel narratives in the eighteenth century should have been mirrored in the disappearance of apodemic literature. Stagl had rightly stressed the pertinence of ars apodemica for the development of knowledge - which is always linked to institutions - and in particular, its importance for the development of the social sciences and their influence on policy making by political institutions. As I have argued from the outset, ascertaining truth based on empirical evidence and the instrumentalization of reports in an institutional 
framework were characteristic of the relation as a practice and a genre. Given this situation, it is no surprise that the epistemic shifts between the sixteenth and eighteenth centuries had a profound and lasting impact. With the changes in what constitutes knowledge and how to obtain it come new scientific methods and discourses.

In some way this "disappearance" of a discourse speaks more to its transformation than to its discontinuity. Starting with the sixteenth century we find a proliferation of discourses and practices which are deeply indebted to travel and its textuality, and which continue beyond the eighteenth century where travel literature and travel relations left off: geography, botany, ethnography, pharmacy, history, antiquarianism, etc. - not to mention "statistics" and its modern descendents, the social sciences. This change doubtless affected the discourse of travel in general, but the institutional infrastructure that comes with it shaped the travel relation even more so. With the establishment of academies, universities, scientific societies, and colonial or bureaucratic agencies of the State, the Church or the private sector, apodemic literature developed into detailed questionnaires and instructions which become increasingly specific and scientific. As a consequence, the travel relation became ever more selective in what, how and to whom it reported. The narrative of field work and empirical inquiry in the field no longer tells its story, but is reduced to sociographic, bureaucratic or scientific data. The proliferation of knowledge with its multiplication and specialization of discourses no longer allows for a coherent and global discourse. If this spells the end of the relation of travel as a genre and as a practice, it also indicates its afterlife.

\section{Notes}

1. Research for this article has been funded by the Social Science and Humanities Research Council of Canada. I thank Michel Fournier, Grégoire Holtz, Vincent Masse, and Jessica Westerhold for valuable assistance.

2. The history of terms like travel, voyage, Reise, journey harbours many insights; see Normand Doiron, L'Art de Voyager. Le déplacement à l'époque classique (SainteFoy: Presses de l'Université Laval, 1995), chapters 1 and 2.

3. On genre definition see Roland LeHuenen, "Qu'est-ce qu'un récit de voyage?", Littérales 7 (1990), pp. 11-27; Réal Ouellet, “Qu'est-ce qu’un récit de voyage?” 
in La recherche littéraire. Objets et méthodes, ed. Claude Duchet and Stéphane Vachon (Montréal: XYZ, 1993), pp. 235-52; Réal Ouellet, "Pour une poétique de la relation du voyage" in Écrire des récits de voyage (XVe-XVIII siècles), Esquisse d'une poétique en gestation, ed. Marie-Christine Pioffet and Andreas Motsch (Québec: Presses de l'Université de Laval, 2008), pp. 17-40 ; Réal Ouellet, La relation de Voyage en Amérique (XVI ${ }^{-}-\mathrm{XVIII}{ }^{e}$ siècles), Au carrefour des genres (Québec: Presses de l'Université de Laval, 2010).

4. The seminal studies are Jacques Chupeau, "Les récits de voyages aux lisières du roman," Revue d'Histoire Littéraire de la France 77.3-4 (1977), pp. 536-53; and Percy G. Adams, Travel Literature and the Evolution of the Novel (Lexington: University Press of Kentucky, 1983).

5. See for example Gilbert Chinard, L'Amérique et le rêve exotique dans la littérature française au XVII et XVIII siècle (Paris: Hachette, 1911); Geoffrey Atkinson, Les relations de voyages $d u X V I I$ e siècle et l'évolution des idées: contribution à l'étude de la formation de l'esprit du XVIII siècle (Paris: Champion, 1924).

6. This discussion is based on: Alain Rey, ed., Dictionnaire historique de la langue française (Paris: Dictionnaires Le Robert, 2003); Dictionnaire du Moyen Français, 1330-1500 (2009 version online http://www.atilf.fr/dmf/); P. G. W. Glare, ed., Oxford Latin Dictionary (Oxford: Clarendon Press, 1996); Oxford English Dictionary Online (Oxford University Press, version dated February 3, 2008).

7. J. L. Austin, How to do things with words (Oxford: Clarendon Press, 1962).

8. This survey is not exhaustive; it is based on the online catalogues of the Bibliothèque nationale de France, the Bayrische Staatsbibliothek, the British Library and the Karlsruher Virtueller Katalog (http://www.ubka.uni-karlsruhe. de/kvk/kvk/kvk_en.html), as well as the database "Bibliographie des voyages" of the Centre de recherche sur la littérature des voyages (http://www.crlv.org/swm/ Page_recherche_viatique.php) and Geoffroy Atkinson's La littérature géographique française de la Renaissance : répertoire bibliographique of 1926 and its Supplément au répértoire... of 1936, both published in Paris by A. Picard.

9. Saewulf's oldest manuscript presents an anomaly as it carries what Huygens calls a "heading" which reads "Incipit certa relatio de situ Ierusalem" while the text itself begins with "Ego Saewlfus licet indignus et peccator Ierosolimam pergens..."; R.B.C. Huygens, ed., Peregrinationes tres, Saewulf, John of Würzburg, Theodoricus, Corpus Christianorum, Continuatio Mediaeualis 139, pp. 59-77 (Turnhout: Brepols, 1994), p. 7. 
10. Johannes Franciscus [de Pavinis], Relatio circa canonizationem beati Bonaventurae (Cologne: Johann Koelhoff der Ältere, ca. 1486-1494).

11. Luís Froís, Nova Relatio Historica De Statu Rei Christianae In Iaponia... (Mainz: Albinus, 1598).

12. Sir Walter Raleigh, The discoverie of the large, rich, and bevvtifyl empire of Guiana with a relation of the great and Golden Citie of Manoa... 1595. (London: Robert Robinson, 1596).

13. Relation of the expongnable attempt and conquest of the yland of Tercera... by Don Albaro de Bacan (London: Thomas Purfoote, n.d.).

14. Francisco Álvarez, Historiale description de l'Ethiopie, contenant vraye relation des terres et païs du grand Roy et Empereur Prete-Jan (Antwerp: Jean Bellere, 1558).

15. Francisco Álvarez, Ho Preste Joam das Indias. Verdadera Informaçam das terras do Preste Joam (Lisbon: L. Rodrigues, 1540).

16. João Bermudez, Breve relação da embaixada que o patriarcha D. João Bermudez trouxe do imperador da Ethiopia, chamado vulgarmente Preste João, dirigida al rei D. Sebastião... (Lisbon: 1565).

17. Hernán Cortéz, Carta segunda de relación... (Seville: Cromberger, 1522).

18. Relazione della vittoria hauuta da monsignor, il duca di Sauoia, contra Francesi, il giorno di s. Lorenzo del 57 sotto santo Quintino (Cremona: Vincenzo Conti, 1557).

19. Giovanni Battista Ramusio, Primo volume e terza editione delle Navigationi et viaggi.... (Venice: Giunti, 1563).

20. Jean-Baptiste Tavernier, Vierzig-Jährige Reise-Beschreibung... (Nuremberg: Hofmann, 1681); of the three parts, parts 1 and 3 feature Relation on the title page.

21. Relation und Extract von aussagen und besonderen Kundtschafften des Türkens eroberung Zigeths, erfolgtauff den 7. tag Septembris, 1566 (Augsburg: Zimmermann, 1566).

22. Relation: Aller Fuernemmen und gedenckwuerdigen Historien so sich hin und wider in Hoch- und Nieder-Teutschland, auch in Frankreich, Italien, Schott und Engelland, Hisspanien, Hungern, Polen, Siebenbürgen, Wallachey, Moldaw, Türcken Inn diesem 1609. Jahr verlauffen und zutragen möchte (Strasbourg: Carolus, 1609).

23. Cortéz's Cartas de relación are a telling example: reporting on military conquest, the land and its people, their title invokes two genres, the letter (carta) and the report (relación); see Ángel Delgado Gómez’s introduction to Hernán Cortés, Cartas de Relación (Madrid: Castalia, 1993), pp. 17, 37-64.

24. To make a deposition about something someone knows about something (my translation). 
25. Sir Francis Drake, The Voyages and travels... into the West-Indies, and round about the world. Giving a perfect relation of his strange adventures, and many wonderful discoveries... (London: printed by M. H. and I. M. for P. Brooksby, 1683).

26. William Lithgow, The totall discourse of the rare adventure... (London: I. Oakes, 1640).

27. William Davies, A true relation of the travels... (London: Thomas Snodham, 1614); Sir Francis Drake, Sir Francis Drake revived... Being a summary and true relation of foure severall voyages... (London: Nicholas Bourne, 1653 [1652]).

28. This text is an example of a relation which does not carry the term in its title. I translate the title of Francesco Carletti, Ragionamenti sopra le cose da lui vedute ne' suoi viaggi dell'Indie occidentali come d'altri paesi, (Florence: Carlieri, 1701); see the preface of Paolo Carile, ed., Voyage autour du Monde de Francesco Carletti (1594-1606) (Paris: Chandeigne, 1999).

29. Carile's preface, pp. 10, 20.

30. "Raisonnements faits en présence du Sérénissime grand-duc de Toscane," is the title used for Carile's edition, p. 51; the translation is mine.

31. Pordenone's testimony was written down in 1330 by the friar William of Solagna; Odoric of Pordenone, "Relatio" in Itinera et Relationes Fratrum Minorum Saeculi XIII et XIV, Anastasius van den Wyngaert, ed., Sinica Franciscana 1, vol. 1 (Florence /Quaracchi: Collegium S. Bonaventurae, 1929), pp. 381-495. Nicolo de Conti's testimony was written down in 1439 by Poggio Bracciolini, the pope's secretary, who published it in his De varietate fortunae; De l'Inde: les voyages en Asie de Niccolò de' Conti : De varietate fortunae livre IV (Turnhout: Brepols, 2004), Latin and French.

32. Ramusio's Navigationi et viaggi.

33. Hakluyt's The Principall Navigations, Voiages, and Discoveries of the English Nation... (London: George Bishop and Ralph Newberie, deputies to Christopher Barker, 1589).

34. The Grand Voyages or the America series consist of fourteen volumes published in up to four languages from 1590 to 1640 and the Petits Voyages or the East Indies series, which counts thirteen volumes, were published in German and Latin between 1597 and 1633, all in Frankfurt by Theodore de Bry and his successors.

35. For the origins of these reports see Léon Pouliot, S.J. Etude sur les Relations des Jésuites de la Nouvelle-France, 1632-1672 (Montréal: Scolasticat de l'ImmaculéeConception, and Paris: Desclée de Brouwer, 1940), chapter 1. 
36. Relation de ce qui s'est passé en la Nouvelle France, en l'année 1633, envoyée au R[évérend] P[ère] Barth. Iaquinot, Provincial de la Compagnie de Jesus en la province de France par le P.[ère] Paul le Jeune de la mesme compagnie, Superieur de la résidence de Kebec (Paris: Cramoisy, 1634). With one exception all titles are printed in Paris by Cramoisy; for details see Alain Beaulieu's online presentation at Library and Archives Canada: http://epe.lac-bac.gc.ca/100/206/301/lac-bac/ jesuit_relations-ef/jesuit-relations/index-e.html.

37. The Lettres édifiantes et curieuses écrites des missions étrangères par quelques missionnaires de la Compagnie de Jésus were published in Paris between 1702 and 1776 by different publishers and were edited first by Father Charles le Gobien and then by Fathers Jean Baptiste Du Halde, Louis Patouillet, and Nicolas Maréchal.

38. Antoine François Prévost, Histoire générale des voyages ou Nouvelle collection de toutes les relations de voyages par mer et par terre, qui ont été publiées jusqu'à présent... (Paris: Didot, 1746-1759), published in fifteen in $-4^{\circ}$ volumes. Initially, Prévost intended merely a translation of John Green's A New General Collection of Voyages and Travel (London: Thomas Astley, 1745-1747), published in four volumes.

39. From the perspective of a poetic performance Homer's Odyssey raises all the central questions. It exemplifies the historic precedence of orality before literacy, but also draws attention to the ambiguous status of poetry as oral performance in an era of print. What is the status of the poet's performance in regard to his text, and how is this different from a traveller giving oral testimony and then publishing his narrative?

40. Johannes Boemus, Omnium Gentium Mores, Leges et Ritus... ex multis clarissimis rerum scriptoribus, (Augsburg: Sigismund Grimm and Marcus Wirsung, 1520). I quote the translation by William Watreman, The Fardle of Facions... (London: John Kingstone and Henry Sutton, 1555) which omits the part on Europe; here $\left[\right.$ Avi ${ }^{\mathrm{r}}$-Avi ${ }^{\circ}$. I discuss Boemus in "La collection des mœurs de Johannes Boemus ou la mise en scène du savoir ethnographique" in Le théâtre de la curiosité, Cahiers V. L. Saulnier 25 (Paris: Presses de l'Université Paris-Sorbonne, 2008), pp. 51-65.

41. Joseph-François Lafitau, Mours des sauvages amériquains comparées aux mours des permiers temps (Paris: Saugrain et Hochereau, 1724), published in two in $-4^{\circ}$ volumes, here vol. 1, pp. 5-6.

42. My presentation draws on Justin Stagl's summary of his research in "Der wohl unterwiesene Passagier" in Boris Illich Krasnobaev et al., Reisen 
und Reisebeschreibungen im 18. und 19. Jahrhundert als Quellen der Kulturbeziehungsforschung (Munich: Camen, 1980), pp. 353-84; here 360-62.

43. Stagl, pp. 360-62.

44. Stagl mentions Theodor Zwinger, Hugo Blotius, Hilarius Pyrckmair and Hieronymus Turler; Turler's English adaptation The Traveiler (London: Veale, 1575) will greatly influence the English tradition.

45. Stagl notes one exception, the English tradition of "politikal Arithmetik" which is quantifying from the seventeenth century onwards (Stagl, p. 354). At the turn of the eighteenth to the nineteenth century the quantitative model becomes dominant, changing the meaning of statistics forever.

46. My exposition is based on Chupeau's "Les récits de voyages... ", which offers an overview of the French context, Adams's treatment of the subject in France and England in his Travel Literature and the Evolution of the Novel, and Friedrich Wolfzettel's, Le discours du voyageur ; pour une histoire littéraire du récit de voyage en France, du Moyen Âge au XVIII siècle (Paris: Presses Universitaires de France, 1996), especially chapter 3. Adams and Wolfzettel's detailed analyses offer countless examples to which for a lack of space I can only allude here.

47. Wolfzettel, pp. 131-32.

48. Letter dated December 15, 1663; Chapelain's correspondence can be found in Jean Chapelain, Opuscules critiques, ed. Alfred C. Hunter (Paris: Droz, 1936), p. 477.

49. Charles Sorel, Bibliothèque françoise (Paris: Compagnie des libraires du Palais, 1667), a vi $\mathrm{r}^{\circ}$ - a vii $\mathrm{r}^{\circ}$, and p. 150.

50. Sorel, p. 146.

51. Fernão Mendez Pinto, Peregrinaçam de Fernam Mendez Pinto... (Lisbon: Pedro Crasbeeck, 1614).

52. Sorel, p. 148.

53. Antoine Furetière, Dictionnaire universel... (The Hague: Piere Husson, Thomas Johnson, Jean Swart, Jean van Duren, Charles Le Vier, La veuve van Dole, 1727), vol. 4, article "voyage"; see also Wolfzettel, pp. 128-34.

54. Chupeau, pp. 541-48; and Wolfzettel, p. 132.

55. See Percy G. Adams's study, Travelers and Travel Liars, 1660-1800 (Berkeley: University of California Press, 1962).

56. Denis Diderot and Jean le Rond D’Alembert, eds., Encyclopédie, ou dictionnaire raisonné des sciences, des arts et des métiers (University of Chicago: ARTFL Encyclopédie Project, Winter 2008 Edition, Robert Morrissey ed., at http:// encyclopedie.uchicago.edu/), vol. 17, p. 477. The Greek quotation translates as 
"Tout homme qui parle des voyages est un vantard," or "Everyone who tells of his travels is a boasting braggart" whereby the Greek $\dot{\alpha} \lambda \alpha \zeta \dot{\omega} v$ clearly implies an untruthful person. I thank Michel Narcy and Jim Carscallen for help with this translation.

57. Chupeau, pp. 540, 548-49; see also Grégoire Holtz, "Le style nu des relations de voyages" in Le Lexique métalittéraire français, $X V I^{e}-X V I I^{e}$ siècles, ed. Michel Jourde and Jean-Charles Monferran (Geneva: Droz, 2006), pp. 165-85.

58. Chupeau, pp. 540-41.

59. Chupeau, p. 541 and, crucially, Adams's Travel Literature and the Evolution of the Novel, chapter 10.

60. Réal Ouellet's critical edition with his substantial introduction remains the reference for all Lahontan studies: Lahontan: Euvres complètes (Montréal: Presses de l'Université de Montréal, 1990), a part of the Bibliothèque du Nouveau Monde, in two volumes. Correcting the imprints, Ouellet establishes as publication date for the French edition the end of 1702 for the first two titles and the end of 1703 for the third; their English translations were published in 1703; see Ouellet, Lahontan, pp. 34-38, 207-38, 1322-48.

61. Nouveaux Voyages de Mr. le Baron de Lahontan dans l'Amérique septentrionale; Qui contiennent une relation des différens Peuples qui y habitent... (The Hague: Frères l'Honoré, 1703).

62. Mémoires de l'Amérique septentrionale ou la suite des voyages de Mr Le Baron de Lahontan; Qui contiennent la Description d'une grande étendue de Païs... (The Hague: Frères l'Honoré, 1703).

63. Suite du voyage de l'Amérique ou Dialogues de Monsieur le Baron de Lahontan et d'un sauvage dans l'Amerique, Contenant une description exacte des mours \& des coutumes de ces Peuples suvages... Avec les voyages du même en Portugal \& en Danemark... (Amsterdam: la veuve de Boeteman, and London: David Mortier, 1704).

64. Claude Le Beau, Les Avantures du Sieur Claude Le Beau, avocat en parlement, ou Voyage curieux et nouveau parmi les Sauvages de l'Amérique Septentrionale. Dans le quel on trouvera une description du Canada, avec une Relation très particulière des anciennes Coutumes... (Amsterdam: Herman Uytwerf, 1738), in two volumes; Andréanne Vallée's critical edition of Le Beau, forthcoming from the Presses de l'Université Laval, is based on her dissertation: Édition critique des "Avantures du Sieur Claude Le Beau. Voyage curieux et nouveau parmi les Sauvages de l’Amérique 
septentrionale" (Ph.D. dissertation, University of Ottawa, Department of French, 2008).

65. Vallée, p. 17.

66. The development is discussed further by Chupeau, by Adams (Travel Literature and the Evolution of the Novel), as well as by Stagl (specifically pp. 376-79).

67. Normand Doiron, "L’Art de voyager. Pour une définition du récit de voyage à l'époque classique," Poétiques (February 1988), pp. 83-108, 90.

68. The situation is comparable in Britain as well as in Germany, but the latter goes through this process with some delay; for Britain see Adams (Travel Literature and the Evolution of the Novel) and for Germany see Stagl ("Der wohl unterwiesene Passagier").

69. Chupeau, pp. 544-51, and Stagl, p. 379. 